\title{
Serum Insulin-Like Growth Factors and Insulin-Like Growth Factor Binding Proteins in the Human Fetus. Relationships with Growth in Normal Subjects and in Subjects with Intrauterine Growth Retardation
}

\author{
CLAUDINE LASSARRE, SYLVIE HARDOUIN, FERNAND DAFFOS, FRANÇOIS FORESTIER, \\ FRANCIS FRANKENNE, AND MICHEL BINOUX
}

Unité de Recherches sur la Régulation de la Croissance, INSERM U.142, Hôpital Saint-Antoine, Paris, France [C.L., S.H., M.B.J, Service de Médecine et de Biologie Foetales, Institut de Puériculture, Paris, France [F.D., F.Fo.J, and Endocrinologie Expérimentale et Clinique, Centre Hospitalier Universitaire, Liege, Belgium [F.Fr.]

\begin{abstract}
IGF-I, IGF-II, and their binding proteins (BP) were studied in sera obtained by direct puncture of umbilical cords in utero between 20 and 37 wk of gestation in 103 normal fetuses and in 16 fetuses with intrauterine growth retardation, as well as in the cord blood of 37 normal newborns of 38- to 42-wk pregnancies. In normal fetuses, IGF-I levels were approximately $50 \mathrm{ng} / \mathrm{mL}$ and IGF-II levels approximately $350 \mathrm{ng} / \mathrm{mL}$ up to the $33 \mathrm{rd}$ wk of pregnancy. Thereafter, both increased to reach values two to three times higher at term. Correlations were found between fetal placental lactogen levels and those of IGF-I and IGF-II, which is consistent with the hypothesis that placental lactogen is involved in the regulation of IGF synthesis in the fetus. With weight (either measured at birth or deduced from echographical data) as index of fetal size, IGF-I levels were significantly $(p<0.001)$ higher in fetuses with weights above the mean for gestational age than in fetuses with weights below the mean, whereas IGFII levels were similar in the two groups. Similarly, IGF-I (but not IGF-II) levels in fetuses with intrauterine growth retardation were significantly lower than those in normal fetuses of the same age $(p<0.01)$. These findings suggest that, during the latter months of intrauterine life, IGF-I (but not IGF-II) is involved in the control of fetal size. Total fetal BP concentrations were approximately $1 / 3$ those of adults. The fetal electrophoretic profile obtained by Western-ligand blotting bore a strong resemblance to that of subjects with growth hormone deficiency. In newborns, the proportions of IGF-I and IGF-II associated with BP to form $150-\mathrm{kD}$ complexes were considerably lower than those in adults, but similar to those in hypopituitary patients. It may be deduced from these findings that during fetal life, BP synthesis is adapted to increase the bioavailability of the IGF at a time when growth is at a maximum. (Pediatr Res 29: 219-225, 1991)
\end{abstract}

\section{Abbreviations}

BP (or IGF-BP), IGF binding protein IUGR, intrauterine growth retardation PL, placental lactogen

Received November 15, 1989; accepted October 8, 1990. Correspondence: Michel Binoux. INSERM U.142, Hôpital Saint-Antoine, 184 rue du Faubourg St-Antoine, 75571 Paris Cédex 12, France.

Supported by the Institut National de la Santé et de la Recherche Médicale (INSERM).
hPL, human placental lactogen

GH, growth hormone

The involvement of IGF in fetal growth has long been suspected and, in view of the developmental switch from IGF-II to IGF-I in the rat $(1,2)$, it has been suggested that IGF-II could be the fetal somatomedin (reviews in 3 and 4). In man, correlations have been seen between body weight or length at birth, somatomedin activity, and IGF levels in cord blood (5-8). Furthermore, IGF-specific receptors have been found in a wide variety of tissues (9-11). More recently, mitogenic effects of IGF on several types of human fetal cells have been demonstrated (12-14). The ubiquitous production of IGF, initially suggested by their presence in extracts of a wide variety of organs and tissues (15), has been confirmed by immunocytochemistry (16) and detection of their mRNA $(17,18)$. Consequently, greater emphasis has been placed on the paracrine action of IGF (19) and doubt thrown on the significance of their circulating levels. However, although IGF mRNA have been found in virtually all human fetal tissues, they are most abundant in fetal liver, where IGF-II expression is much higher than IGF-I expression (18). It can therefore be postulated that circulating IGF levels reflect IGF production in the liver, as has been shown in the rat (20), and that IGF have an endocrine action.

The bioavailability of the IGF is in large part determined by the relative proportions of specific BP (review in 21), of which we have identified five molecular forms in man, each differing in its regulation and its affinities for IGF-I and IGF-II $(22,23)$.

The purpose of our study was to measure serum IGF and BP levels in the course of the development of the human fetus and to analyze their relationships with fetal size in normal subjects and in cases of IUGR.

\section{MATERIALS AND METHODS}

Serum samples. Fetal serum samples were obtained by direct puncture of the umbilical cord in utero as previously described (24). 1) Between 20 and 37 wk of pregnancy, 103 samples were taken for prenatal diagnosis of mother-to-fetus transmissible infection. In all the cases selected for this study, the mothers had recovered from their infection, the fetuses tested negative, pregnancy continued to term, and the newborns were healthy and of normal birth weight. There were no cases of maternal glucose 


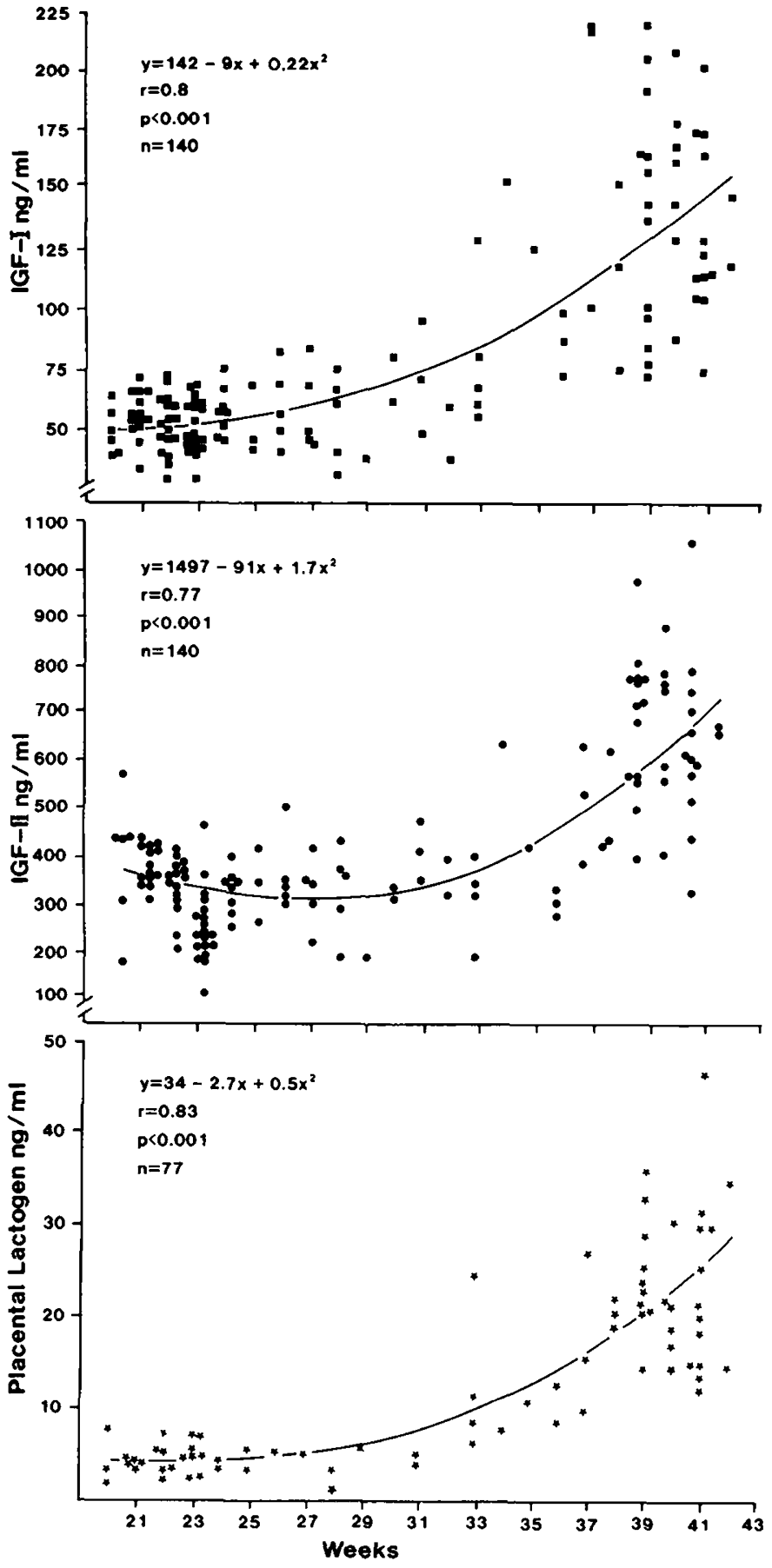

Fig. 1. Changes in serum IGF-I, IGF-II, and PL levels with gestational age in normal fetuses.

intolerance. The results of assays done on these samples were therefore considered as normal reference values. 2) Sixteen severely growth-retarded fetuses were sampled for a variety of investigations, in particular karyotype determination. In none of the cases selected for this study were any disorders detected that might account for the IUGR.

Cord blood was collected from 37 normal newborns ( 38 to 42 wk of pregnancy). Fetal age was expressed in wk from the 1st d of the last menstrual period.

Comparisons were made with individual or pooled samples of normal adult serum (mean age of the subjects, $28 \mathrm{y}$ ) as well as with samples from 18 untreated subjects suffering from idiopathic $\mathrm{GH}$ deficiency ( $\mathrm{GH}$ level below $5 \mathrm{ng} / \mathrm{mL}$ in two stimulation tests).

Indices of growth. Weight was c iosen as the index of fetal size.
Estimations of fetal weight were based on echographical data, according to Warsof et al. (25). Fetuses were classified as "large" or "small" on the basis of their weight being above or below the 50th percentile for fetuses of the same age. Newborns were classified in the same way using the 50th percentile of the weightto-gestational-age curve established by Leroy and Lefort (26). In the 16 cases of IUGR, diagnosis was confirmed by measurement of birth weight that was below the 3rd percentile.

$I G F-I, I G F-I I$, and binding activity measurements. These assays have been described in detail previously $(27,28)$. Samples were gel filtered on $1.5 \times 30 \mathrm{~cm}$ columns of Ultrogel AcA 54 (IBF, Villeneuve-La-Garenne, France) in $1 \mathrm{M} \mathrm{CH}{ }_{3} \mathrm{COOH}, 0.15$ $\mathrm{M} \mathrm{NaCl}, 0.1 \%$ BSA. BP were collected in the material eluting between 47 and $66 \%$ of the bed volume and IGF in that eluting between 77 and $90 \%$. The eluates were lyophilized and then desalted on Sephadex G 25 disposable columns (Pharmacia, Uppsala, Sweden) in the assay buffer.

Pure IGF-I (preparation 1:4) and IGF-II (preparation 9 SE IV) purified from human serum were generously provided by $\mathrm{Dr}$. $\mathrm{R}$. E. Humbel (Zurich, Switzerland) and were used as standards and as tracer after iodination by the chloramine $\mathrm{T}$ method.

IGF-I was assayed by RIA using the anti-IGF-I antiserum prepared by Drs. L. Underwood and J. J. Van Wyk (Chapel Hill, NC) and kindly provided by the Hormone Distribution Program, NIDDK, University of Maryland School of Medicine. IGF-II was measured by competitive protein binding assay using BP extracted from human cerebrospinal fluid, which have a selective affinity for IGF-II. IGF-I and IGF-II were assayed simultaneously. Unknown samples were studied at three concentrations, each in duplicate, plus one blank (tube without antibody or BP).

For the binding activity measurements, the relative BP concentration in each sample was assessed in terms of its binding to ${ }^{125}$ I-IGF-I compared with a reference BP preparation extracted from a pool of normal serum and arbitrarily assigned a value of $1 \mathrm{U} \mathrm{BP} / \mathrm{mL}$. Samples were studied at six concentrations, each in duplicate.

Incubations were done at $4^{\circ} \mathrm{C}$ in $0.1 \mathrm{M}$ sodium phosphate buffer, $\mathrm{pH} 7.5,0.2 \%$ BSA (total volume, $0.4 \mathrm{~mL}$ ) for $3 \mathrm{~d}$ in the case of the IGF-I RIA and for 18-24 h in the case of the IGF-II and binding activity assays. Free and bound IGF were separated using albumin-coated charcoal.

For the IGF-I and IGF-II assays, the intraassay coefficient of variation was $4 \%$ and the interassay coefficient (including the gel filtration step) was $15 \%$. For binding activity, these values were 6 and $18 \%$, respectively.

Preparation of the 150-kD and 40-kD IGF-BP complexes. The technique has been described in detail elsewhere (29). Briefly, serum samples were gel filtered on $1.6 \times 40 \mathrm{~cm}$ columns of Ultrogel AcA 44 in $0.02 \mathrm{M}$ Tris- $\mathrm{HCl}, \mathrm{pH} 7.4,0.15 \mathrm{M} \mathrm{NaCl}$, $0.1 \%$ BSA, $0.05 \% \mathrm{NaN}_{3}$. The $150-\mathrm{kD}$ complexes were collected in the material eluting between 4 and $15 \%$ of the bed volume and the $40-\mathrm{kD}$ complexes in that eluting between 24 and $46 \%$. The eluates were lyophilized and then submitted to acidic gel filtration for IGF-I and IGF-II measurement.

Western-ligand blotting. The method has been described in detail elsewhere (30). Samples ( 3 or $6 \mu \mathrm{L}$ serum) were diluted in $0.06 \mathrm{M}$ Tris- $\mathrm{HCl}, \mathrm{pH} 6.8,0.15 \mathrm{M} \mathrm{NaCl}$, then supplemented with $5 \%$ SDS, $10 \%$ glycerol, $0.02 \%$ bromophenol blue, heated at $60^{\circ} \mathrm{C}$ for $20 \mathrm{~min}$, and finally submitted to $11 \%$ homogenous gel SDSPAGE in the absence of reducing agent [except in the case of the ${ }^{14} \mathrm{C}$-labeled reference proteins (Amersham, UK)]. Running conditions were constant voltage $(60 \mathrm{~V})$ for about $15 \mathrm{~h}$, then constant current $(30 \mathrm{~mA} / \mathrm{gel})$ until the marker dye exited. The proteins were then electroblotted onto a nitrocellulose sheet for $2 \mathrm{~h}$ under constant current (1 A). After quenching of the nitrocellulose at $4^{\circ} \mathrm{C}$ with Nonidet P 40 (Sigma Chemical Co., St. Louis, MO), BSA, and Tween 20 and 24 or 36 h of incubation with 200000 cpm ${ }^{125} \mathrm{I}-\mathrm{IGF}-\mathrm{I}$ or $-\mathrm{II}$ at $4^{\circ} \mathrm{C}$, the BP were detected by autoradiography. The specificity of the binding was checked by incuba- 
Table 1. Serum levels of IGF-I and IGF-II and IGF-II/IGF-I ratios in normal fetuses and newborns*

\begin{tabular}{|c|c|c|c|c|c|c|c|c|c|c|}
\hline & \multicolumn{7}{|c|}{ Fetus } & \multirow{2}{*}{$\frac{\text { Newborn }}{38-42}$} & \multirow[t]{2}{*}{ Adult } & \multirow[t]{2}{*}{$\begin{array}{l}\text { Hypopituitary } \\
\text { patient }\end{array}$} \\
\hline Wk & $20-22$ & & 23 & & $24-32$ & $33-37$ & & & & \\
\hline$n$ & 37 & & 19 & & 34 & 13 & & 37 & 22 & 18 \\
\hline \multirow[t]{2}{*}{ IGF-I (ng/mL) } & $53 \pm 1.8$ & & $51 \pm 2.6$ & & $58 \pm 2.7$ & $113 \pm 15$ & & $138 \pm 6.7$ & $300 \pm 12$ & $58 \pm 7$ \\
\hline & & NS & & NS & & & NS & & & \\
\hline \multirow[t]{2}{*}{ IGF-II $(\mathrm{ng} / \mathrm{mL})$} & $373 \pm 12$ & & $255 \pm 18$ & & $345 \pm 12$ & $401 \pm 37$ & & $660 \pm 27$ & $1318 \pm 56$ & $471 \pm 56$ \\
\hline & & $p<0.001$ & & $p<0.001$ & & & $p<0.0(0) !$ & & & \\
\hline \multirow[t]{2}{*}{ IGF-II/IGF-I } & $7.3 \pm 0.3$ & & $5.0 \pm 0.2$ & & $6.2 \pm 0.3$ & $3.8 \pm 0.2$ & & $5.1 \pm 0.3$ & $4.5 \pm 0.3$ & $8.9 \pm 0.6$ \\
\hline & & $p<0.001$ & & NS & & & NS & & & \\
\hline
\end{tabular}

* Age is expressed in wk of amenorrhea. Values shown are means \pm SEM. The $t$ test was used for comparison of means. The values in normal adults and patients with idiopathic GH deficiency are shown for purposes of comparison.
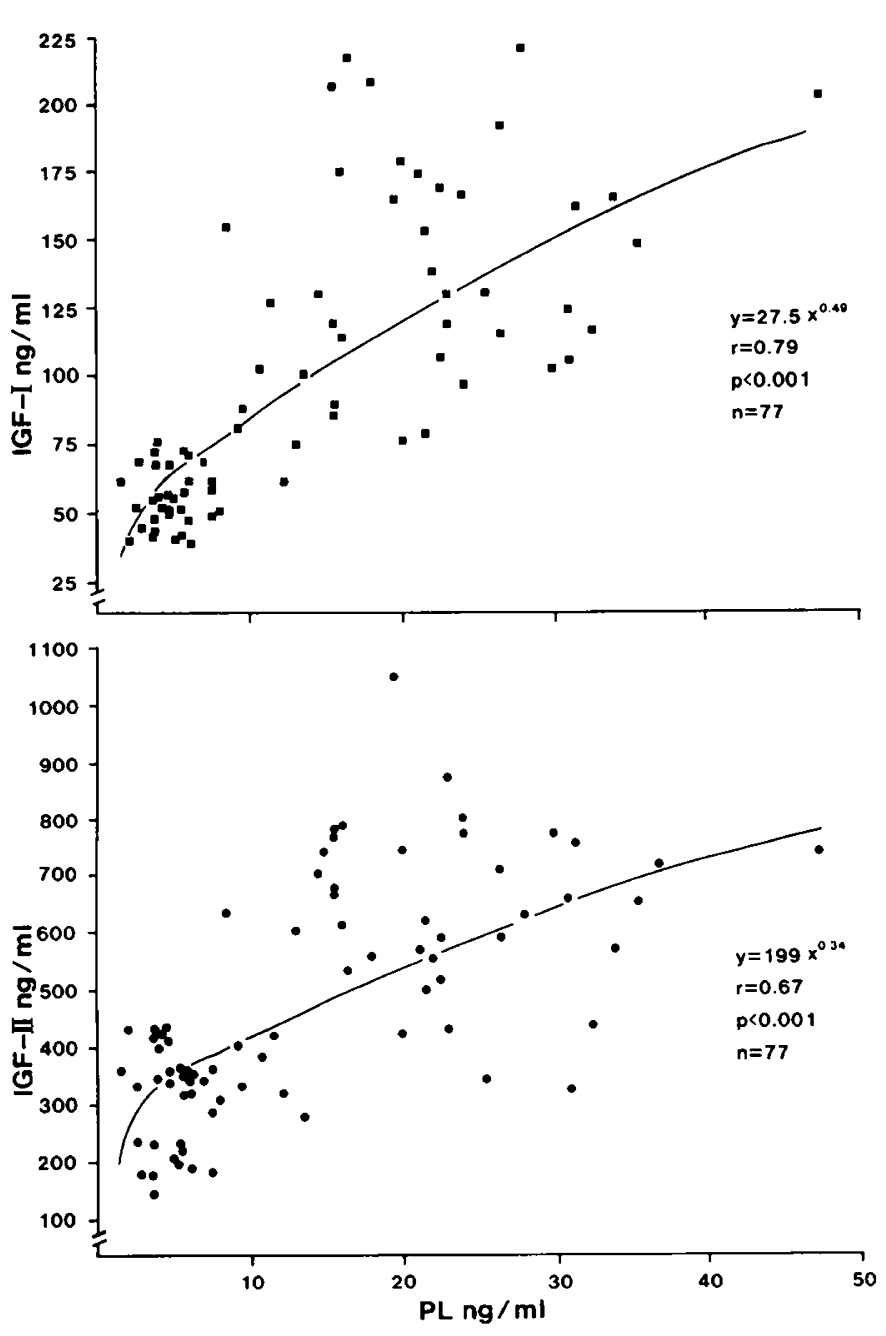

Fig. 2. Relationships between fetal serum levels of PL and of IGF-I and IGF-II.

tion of part of the BP-containing nitrocellulose with excess unlabeled IGF.

$P L$ assay. hPL was measured by RIA using a rabbit anti-hPL antiserum prepared in the Laboratoire d'Endocrinologie Expérimentale et Clinique (Liège, Belgium). Briefly, serum samples $(20 \mu \mathrm{L})$ or standards were preincubated for $1.5 \mathrm{~h}$ with the antiserum (final dilution, 1:250 000) in a total volume of 200 $\mu \mathrm{L}$, then incubated for $16 \mathrm{~h}$ after the addition of ${ }^{125} \mathrm{I}-\mathrm{hPL}$ (50 $000 \mathrm{cpm}, \sim 0.2 \mathrm{ng}$ in $100 \mu \mathrm{L}$ ). Bound-free separation was achieved by a 20 -min incubation with $1 \mathrm{~mL}$ preprecipitated goat second antibody (PPA, UCB Bioproducts, Brussels, Belgium) followed by centrifugation at $2000 \times g$ for $20 \mathrm{~min}$. Highly purified hPL used for labeling and standards were obtained from UCB Bioproducts and calibrated against the WHO-MRC 73/ 545 IRP. The intra- and interassay coefficients of variation were 8 and $15 \%$, respectively, and the cross-reactivity of pituitary $\mathrm{hGH}$ in this assay was $0.1 \%$.

Statistics. Regression curves and correlation coefficients were obtained using a nonlinear adjustment (quadratic and exponential functions) justified by the very characteristic appearance of the groups of plots. Means were compared using conventional methods ( $t$ test, variance, and covariance analysis). An IBMcompatible PC was used with BMDP Statistical Software (Los Angeles, CA) and DYNA-STAT 3.3 software (Dynamic Microsystems, Washington, DC).

\section{RESULTS}

IGF and PL Levels as Function of Age (Fig. 1, Table 1). Fetal IGF-I concentrations averaged $50 \mathrm{ng} / \mathrm{mL}$ up to $33 \mathrm{wk}$ of pregnancy. Thereafter, they increased 2- to 3-fold at term. IGF-II levels increased from approximately $350 \mathrm{ng} / \mathrm{mL}$ to twice that level at birth.

Apart from the earlier stages, where the regression curve for IGF-II dropped, changes in IGF-I and IGF-II levels were roughly parallel.

PL levels in fetal blood increased with gestational age in parallel with those of IGF from a mean of $5 \mathrm{ng} / \mathrm{mL}$ at the first stages of observation to four to six times that level at birth. These increases with age, which are illustrated in Figure 1 where the values obtained for cord blood are included, were also clearly evident when cord blood values were excluded. Variance analysis of values for fetuses at wk 20-22, 23, 24-32, and 33-37 gave highly significant differences for IGF-I $(p<0.001)$, IGF-II $(p<0.002)$, and PL $(p<0.001)$.

Relationships between IGF and PL Levels. The regression curves for IGF-I and IGF-II versus PL levels are shown in Figure 2. Covariance analysis was used to test correlations between PL, IGF-I, and IGF-II. Two periods were considered: that before and that after the 33rd wk of gestation. No correlation was found before wk 33, but after wk 33 there were significant $(p<0.05)$ correlations between PL and both IGF-I and IGF-II levels. Covariance analysis also showed that the differences between the regression curves were significant $(p<0.001)$.

Relationships between IGF Levels and Fetal Size. Normal fetuses (Fig. 3). The fetuses were divided into two groups on the basis of growth: those with weights above the mean for gestational age (large) and those with weights below the mean (small).

When IGF values were plotted as a function of age, the regression curve for IGF-I in large fetuses was clearly above that in small fetuses, whereas the regression curves for IGF-II in the 

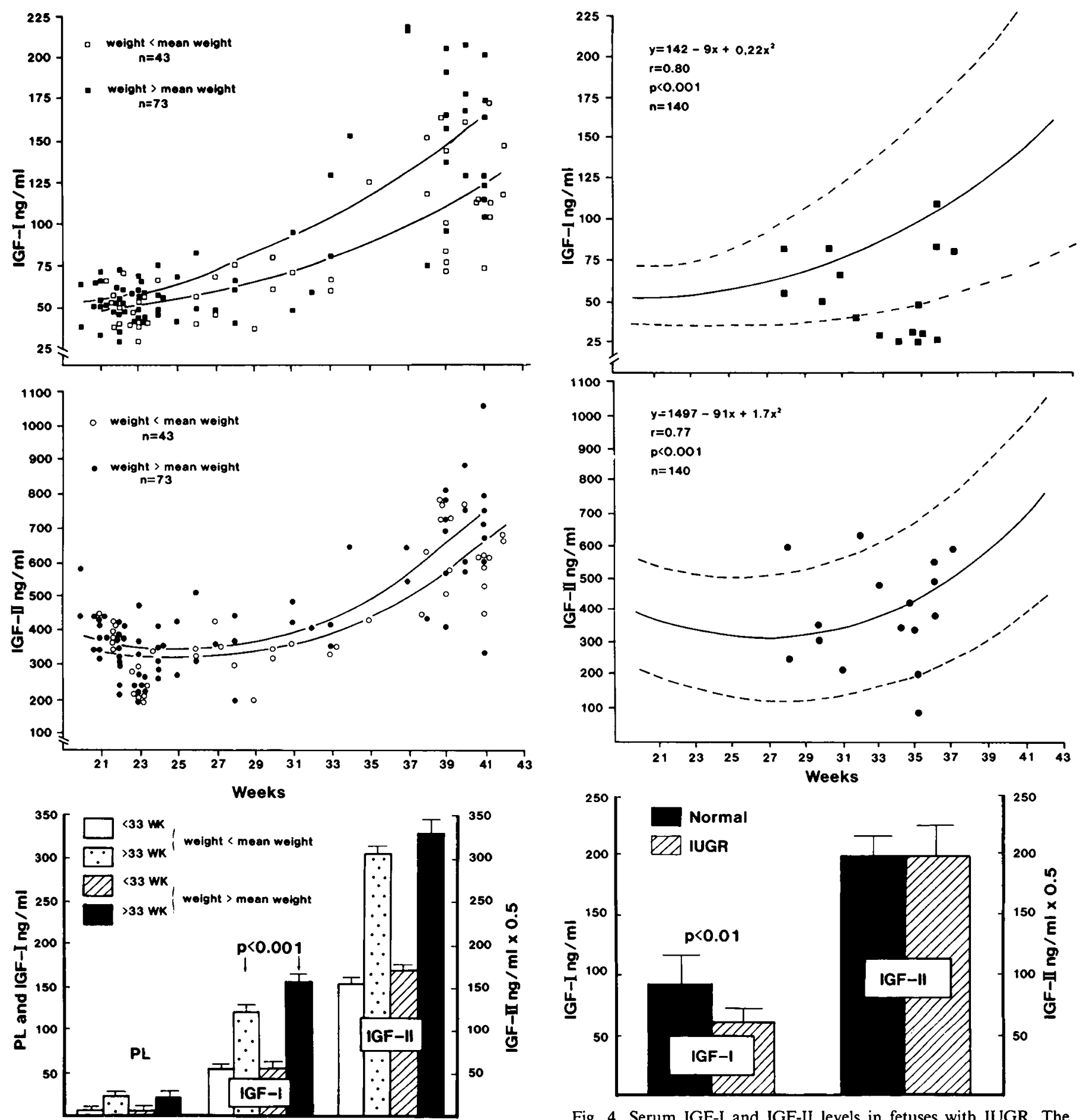

Fig. 3. Relationships between IGF levels and fetal size. The two upper graphs represent serum IGF-I and IGF-II levels as a function of age, separated into two groups on the basis of weight above or below the mean for the age (see Materials and Methods). The graph at the bottom shows a comparison between PL, IGF-I, and IGF-II levels as a function of weight in fetuses before and after wk 33 (see Results).

two groups were very close. Variance analysis showed that when all ages were included there was a significant difference between large and small fetuses $(p<0.001)$ in IGF-I but not IGF-II levels. Separate analysis of the data from early (before wk 33) and late (after wk 33) gestation revealed that for PL and IGF-II there were no significant differences in either category of gestational age between large and small fetuses. For IGF-I, by contrast, although there was no significant difference before wk 33 , the difference after wk 33 was highly significant $(p<0.001)$.

Fig. 4. Serum IGF-I and IGF-II levels in fetuses with IUGR. The regression lines correspond to IGF levels in normal fetuses (mean and 95\% confidence interval). At the bottom, IGF levels are compared in fetuses with IUGR and normal fetuses of the same age (see Results).

Intrauterine growth retardation (Fig. 4). When IGF levels measured between wk 28 and 37 in 16 subjects with IUGR were plotted as a function of gestational age, IGF-I was below the mean for normal fetuses in 13 cases, whereas IGF-II fell on either side of the normal curve. Variance analysis showed that IGF-I levels were significantly lower than those in normal fetuses $(p<$ 0.01 ), but IGF-II levels were similar to normal.

Analysis of IGF BP. Binding activity measured in eight serum samples from 21 - to 24-wk-old fetuses was $0.36 \pm 0.03$ (SEM) $\mathrm{U} / \mathrm{mL}$, which is $1 / 3$ of that in adults $(1.06 \pm 0.07 \mathrm{U} / \mathrm{mL}, n=12)$. With electrophoretic analysis of the BP (Fig. 5), twice the amount of fetal serum was needed to obtain bands of similar intensity to 


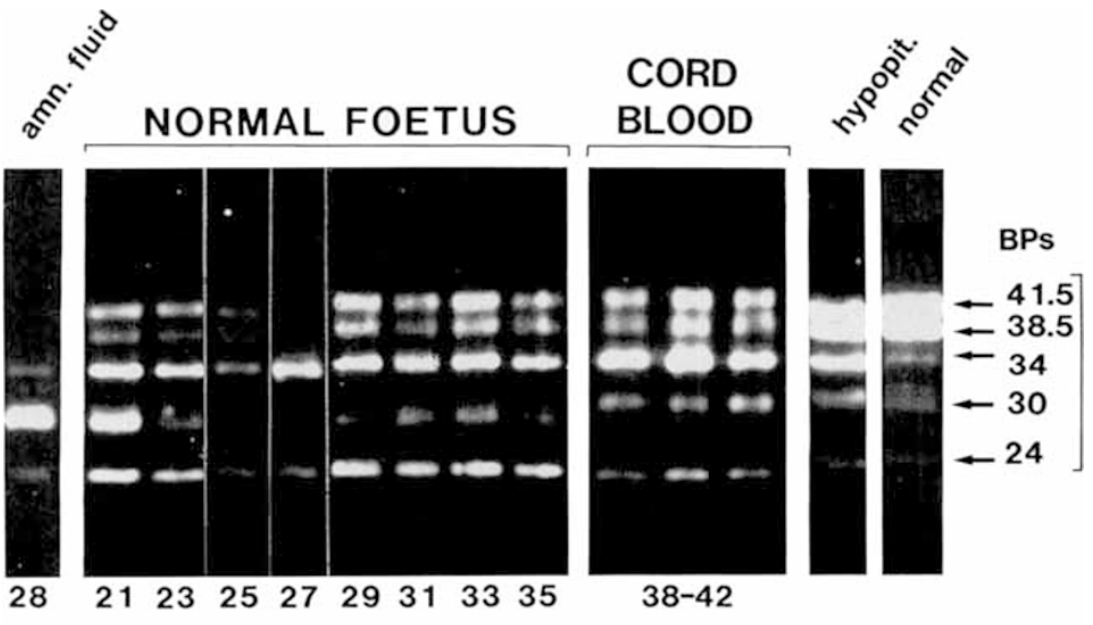

Intra-uterine growth retardation

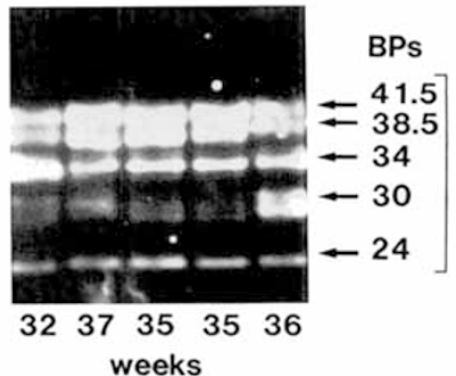

Fig. 5. Western-ligand blot analysis of serum IGF BP as a function of fetal age. The electrophoretic profiles of serum BP in normal fetuses and in fetuses with intrauterine growth retardation $(6 \mu \mathrm{L})$ are compared with those of amniotic fluid $(10 \mu \mathrm{L})$ and normal and hypopituitary serum pools $(3 \mu \mathrm{L})$. The molecular masses of the $\mathrm{BP}$ are expressed in $\mathrm{kD}$. According to recent nomenclature (42), the 41.5 and $38.5 \mathrm{~K}$ forms correspond to IGFBP-3, the $34 \mathrm{~K}$ form to IGFBP-2, and the $30 \mathrm{~K}$ form to IGFBP-1.

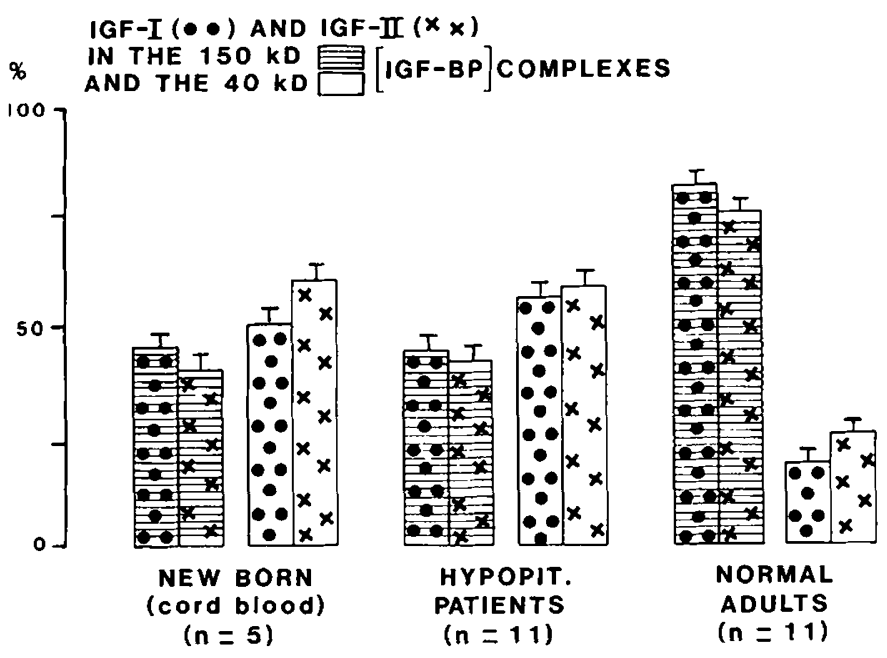

Fig. 6. Proportions of IGF-I and IGF-II in the $150-\mathrm{kD}$ and $40-\mathrm{kD}$ complexes in cord blood: Comparison with those in hypopituitary patients and normal adults. The complexes were isolated by gel filtration at $\mathrm{pH} 7.4$, then submitted to acidic gel filtration to separate the IGF from the BP before assaying (see Materials and Methods). The results (means \pm SEM) are expressed as percentages of IGF-I or IGF-II measured in each complex.

those obtained with adult samples. Qualitatively, the fetal profiles resembled those of patients with $\mathrm{GH}$ deficiency: 1) small amounts of the 41.5- and 38.5-kD BP, which increased slightly toward term (these BP are predominant in normal adults and children over the age of 3 ); 2) a consistently increased $34-\mathrm{kD}$ form; and 3) a sometimes moderately, but generally markedly, increased $30-\mathrm{kD}$ form. Close analysis revealed that in the fetus this form migrated slightly faster than the postnatal serum form, like the corresponding form found in amniotic fluid $(\approx 28 \mathrm{kD})$. The profiles shown in the figure are representative of all the sera tested. The changes in expression of the different BP seen in some samples were unrelated to fetal age. In newborns, the 30$\mathrm{kD}$ material appeared as a doublet, the faster-moving, less abundant form migrating like the fetal form, and the slower-moving, more abundant form migrating like the postnatal form. Another feature peculiar to the fetus was the increased 24-kD form.

In the five cases of IUGR analyzed, the BP profiles resembled those of newborns more than those of fetuses of the same age, with more abundant 41.5- and 38.5-kD BP and a 30-kD BP appearing as a doublet.

Distribution of the IGF among the 150-kD and 40-kD IGF-BP Complexes. Figure 6 shows the relative proportions of IGF-I and IGF-II measured in the material containing either $150-\mathrm{kD}$ or 40 kD IGF-BP complexes separated by neutral $\mathrm{pH}$ gel filtration.

In normal adults, approximately $75 \%$ of both IGF-I and IGFII are found in the $150-\mathrm{kD}$ and $25 \%$ are found in the $40-\mathrm{kD}$ complexes. In newborns (cord blood), as in hypopituitary patients, the IGF are similarly distributed among the two types of complex, with a slight preference for the $40-\mathrm{kD}$ complexes.

\section{DISCUSSION}

Investigation of the changes in serum IGF-I and IGF-II levels from the 20th wk of fetal life until birth yielded two major findings. First, IGF-II levels were four to seven times those of 
IGF-I. The highest IGF-II/IGF-I ratios were seen between wk 20 and 22. In view of IGF-I and IGF-II levels in liver culture media (23) and of mRNA in tissue extracts (18), these levels could reflect predominant IGF-II synthesis in human fetal liver.

Secondly, IGF-I and IGF-II levels rose during the last two mo of fetal life. In man, hepatic synthesis does not appear to switch from IGF-II toward IGF-I, as it does in the rat during the neonatal period when serum IGF-II levels crash (1). This may be because in man expression of the IGF-II gene in the fetal liver is controlled by two promoters $\left(\mathrm{P}_{2}\right.$ and $\left.\mathrm{P}_{3}\right)$, whereas after birth it is controlled by another $\left(\mathrm{P}_{1}\right)(31)$. Both IGF-II and IGF-I levels are lower in the fetus than in children and adolescents (results not shown) and in adults. They are of the same order of magnitude as those of patients with total GH deficiency. It is well known that the $\mathrm{GH}$ secreted by the fetal human hypophysis fails to influence the synthesis of IGF in the liver because of the immaturity of GH receptors (review in 32). However, the small amounts of PL passing into the fetal circulation are capable of interacting with its hepatic receptors whose specificity has now been demonstrated (33). Analysis of our data showed that, after the 33rd wk of gestation, correlations exist between serum levels of both IGF-I and PL, and IGF-II and PL. This suggests that PL may have some regulatory role in IGF biosynthesis by human fetal liver, as has been shown in cultured fetal hepatocytes (34). Also, Hill et al. (33) found the weight of the human fetus to correlate positively with PL-binding capacity of the liver and to a lesser extent with plasma PL concentrations. Furthermore, placental GH, whose levels in the maternal circulation are compatible with interaction with GH receptors, is not detectable in fetal blood (35).

The role of the IGF in fetal statural growth and weight increase remains poorly understood. Years ago, some studies demonstrated correlations between IGF levels and either weight or size at birth (5-8). More recently, Ashton et al. (36) have found correlations between levels of IGF-I (but not of IGF-II) and fetal weight and length, as well as placental weight. In a study of fetal human chondrocytes in culture, IGF-II was reported to have a greater mitogenic capacity than IGF-I (13).

Our findings agree with those of Ashton et al. (36) in that we see a significant correlation between IGF-I levels and fetal weight, but no such relationship for IGF-II. However, we have found no relationship between IGF-I levels and birth length (results not shown). In the 16 subjects with IUGR, IGF-I levels were significantly lower than in normal fetuses of the same age, whereas IGF-II levels were similar. Our earlier findings that 19- to 24wk-old hypotrophic fetuses have depressed serum growth-promoting activity (37) are relevant here, as is an earlier report showing low somatomedin activity in cord serum from infants with IUGR (38). DeChiara et al. (39) have recently used homologous recombination to obtain heterozygous mice that carry an inactivated IGF-II gene and that as a result are growth deficient. It would appear that the mutation exerts its effect early, during the embryonic period. Our data suggest that IGF-I, but not IGFII, is involved in the control of fetal size, at least during the final months of intrauterine life. This, however, does not exclude paracrine and/or autocrine action of IGF-I and IGF-II in the processes of cell growth and differentiation (19).

The electrophoretic profile of the IGF-binding proteins during fetal life strongly resembles that of patients with GH deficiency (29). The 41.5- and 38.5-kD BP, which appear in small quantities in the fetus, represent the two molecular forms of the BP purified from serum (40), whose cDNA has been cloned (41) and which is now known as IGFBP-3 (42). They bind IGF to form either binary complexes eluting in gel filtration around $40 \mathrm{kD}$, or, in association with a nonbinding subunit, ternary complexes of about $150 \mathrm{kD}$ whose synthesis appears to be GH-dependent (21, 22 ). The $30-\mathrm{kD}$ and especially the $34-\mathrm{kD}$ forms are strongly expressed in the fetus and, after birth, seem to be negatively controlled by $\mathrm{GH}$, inasmuch as they are increased in hypopituitarism and barely detectable in acromegaly (29). The $30-\mathrm{kD}$ form corresponds to a BP that has been purified from amniotic fluid $(43,44)$ and Hep G2 human hepatoma culture medium (45), whose cDNA has been cloned $(46,47)$ and which is named IGFBP-1 (42). The $34-\mathrm{kD}$ BP characteristically predominates in cerebrospinal fluid and has a selective affinity for IGF-II (48). The hepatic form has recently been cloned from a liver cDNA library and named IGFBP-2 (49). The 34-, 30-, and 24-kD BP associate with IGF to form only binary complexes (22).

The circulating form of the IGF-II/mannose 6-phosphate receptor has been detected in monkey cord serum and found to be associated to approximately $20 \%$ IGF-II (50). With the type of gel we use for the chromatographic separation of the $150-\mathrm{kD}$ and $40-\mathrm{kD}$ complexes in human cord serum, possible coelution of receptor with the $150-\mathrm{kD}$ complexes cannot be excluded. Nevertheless, the relative proportions of IGF-I and IGF-II in pooled fractions containing both complexes were almost identi$\mathrm{cal}$, with a slight preference for the $40-\mathrm{kD}$ complexes. This resembles the picture in GH-deficient patients. In normal adults, 70 to $80 \%$ of the IGF are associated with the $41.5-$ and $38.5-\mathrm{kD}$ $\mathrm{BP}$ in the form of $150-\mathrm{kD}$ complexes. Our results differ from those of D'Ercole et al. (51) who found somatomedin-C/IGF-I eluting from gel filtration essentially around $40 \mathrm{kD}$ in fetuses of $27 \mathrm{wk}$ or less, but mostly with the $150-\mathrm{kD}$ material in fetuses of $30 \mathrm{wk}$ or more. Physiologically, it is important to remember that the binary $40-\mathrm{kD}$ complexes are capable of crossing the capillary barrier, whereas the ternary $150-\mathrm{kD}$ complexes are not (52), which means that the circulating half-lives of the IGF depend on the relative proportions of these complexes (53). Consequently, the situation in the fetus would favor transport of the IGF toward their target cells and, therefore, turnover. During fetal life, when IGF circulate at very low levels compared with those in adolescents and adults, BP synthesis would therefore be adapted to increase the bioavailability of the IGF at a time when growth is at maximum.

Acknowledgments. The authors thank Jean Meunier for his help in the computer analysis of the data.

\section{REFERENCES}

1. Moses AC, Nissley SP, Short PA, Rechler MM, White RM, Knight AB, Higa OZ 1980 Increased levels of multiplication-stimulating activity, an insulinlike growth factor, in fetal rat serum. Proc Natl Acad Sci USA 77:3649-3653

2. Adams SO, Nissley SP, Handwerger S, Rechler MM 1983 Developmental patterns of insulin-like growth factor I and II synthesis and regulation in rat fibroblasts. Nature 302:150-153

3. Underwood LE, D'Ercole AJ 1984 Insulin and insulin-like growth factors/ somatomedins in fetal and neonatal development. In: Daughaday WH (ed) Clinics in Endocrinology and Metabolism, Vol 13. Saunders, Philadelphia, pp 69-89

4. Rechler MM, Yang YWH, Brown AL, Romanus JA, Adams SO, Kiess W, Nissley SP 1988 Insulin-like growth factors in fetal growth. In: Bercu BB (ed) Basic and Clinical Aspects of Growth Hormone. Plenum Press, New York, pp 233-249

5. Gluckman PD, Brinsmead MW 1976 Somatomedin in cord blood: relationship to gestational age and birth size. J Clin Endocrinol Metab 43:1378-1381

6. Ashton IK, Vesey J 1978 Somatomedin activity in human cord plasma and relationship to birth size, insulin, growth hormone, and prolactin. Early Hum Dev 2:115-122

7. Bennett A, Wilson DM, Liu F, Nagashima R, Rosenfeld RG, Hintz RL 1983 Levels of insulin-like growth factors 1 and $I I$ in human cord blood. J Clin Endocrinol Metab 57:609-612

8. Gluckman PD, Johnson-Barret JJ, Butler JH, Edgar BW, Gunn TR 1983 Studies of insulin-like growth factor I and II by specific radioligand assays in umbilical cord blood. Clin Endocrinol (Oxf) 19:405-413

9. Deal CL, Guyda HJ, Lai WH, Posner BI 1982 Ontogeny of growth factor receptors in the human placenta. Pediatr Res 16:820-826

10. Sara VT, Hall K, Misaki M. Fryklund L, Christensen N, Wetterberg L 1983 Ontogenesis of somatomedin and insulin receptors in the human fetus. J Clin Invest 71:1084-1094

11. Grizzard JD, D'Ercole AJ, Wilkins JR, Moats-Staats BM, Williams RW 1984 Affinity-labeled somatomedin-C receptors and binding proteins from the human fetus. J Clin Endocrinol Metab 58:535-543

12. Hill DJ, Crace CJO, Strain AJ, Milner RDG 1986 Regulation of amino acid uptake and deoxyribonucleic acid synthesis in isolated human fetal fibroblasts and myoblasts: effect of human placental lactogen, somatomedin-C, multiplication-stimulating activity, and insulin. J Clin Endocrinol Metab 62:753-760 
13. Vetter U. Zapf J, Heit W, Helbing G, Heinze E, Froesch ER, Teller WM 1986 Human fetal and adult chrondrocytes. Effect of insulin-like growth factors and II, insulin and growth hormone on clonal growth. J Clin Invest 77:19031908

14. Conover CA, Rosenfeld RG, Hintz RL 1986 Hormonal control of the replication of human fetal fibroblasts: role of somatomedin C/insulin-like growth factor I. J Cell Physiol 128:47-54

15. D'Ercole AJ, Hill DJ, Strain AJ, Underwood LE 1986 Tissue and plasma somatomedin-C/insulin-like growth factor I concentration in the human fetus during the first half of gestation. Pediatr Res 20:253-255

16. Han VKM, Hill DJ, Strain AJ, Towle AC, Lauder JM, Underwood LE, D'Ercole AJ 1987 Identification of somatomedin/insulin-like growth factor immunoreactive cells in the human fetus. Pediatr Res 22:245-249

17. Scott J, Cowell J, Robertson ME, Priestley YLM, Wadey R, Hopkins B Pritchard J, Bell GI, Rall LB, Graham CF, Knott TJ 1985 Insulin-like growth factor-II gene expression in Wilms' tumour and embryonic tissues. Nature $317: 260-262$

18. Han VKM, Lund PK, Lee DC, D’Ercole AJ 1988 Expression of somatomedin/ insulin-like growth factor messenger ribonucleic acids in the human fetus: identification, characterization, and tissue distribution. J Clin Endocrino Metab 66:422-429

19. D'Ercole AJ 1987 Somatomedin/insulin-like growth factors and fetal growth J Dev Physiol 9:481-495

20. Schwander C, Hauri C, Zapf J, Froesch ER 1983 Synthesis and secretion of insulin-like growth factor and its binding protein by the perfused rat liver: dependence on growth hormone status. Endocrinology 1 13:297-305

21. Baxter RC, Martin JL 1989 Binding proteins for the insulin-like growth factors: structure, regulation and function. Prog Growth Factor Res 1:49-68

22. Hardouin S, Hossenlopp P, Segovia B, Seurin D, Portolan G, Lassarre C Binoux M 1987 Heterogeneity of insulin-like growth factor binding protein and relationships between structure and affinity. 1. Circulating forms in man. Eur J Biochem 170:121-132

23. Hossenlopp P, Seurin D, Segovia B, Portolan G, Binoux M 1987 Heterogeneity of insulin-like growth factor binding proteins and relationships between structure and affinity. 2. Forms released by human and rat liver in culture. Eur J Biochem 170:133-142

24. Daffos F, Capella-Pavlovsky M, Forestier F 1985 Fetal blood sampling during pregnancy with needle guided by ultrasound. A study of 606 consecutive cases. Am J Obstet Gynecol 153:655

25. Warsof SL, Gohari P, Berkowitz RL. Hobbins JC 1977 The estimation of fetal weight by computer-assisted analysis. Am J Obstet Gynecol 128:881-892

26. Leroy B, Lefort $F 1971$ A propos du poids et de la taille des nouveau-nés à la naissance. Rev Fr Gynecol Obstet 66:391-396

27. Binoux M. Seurin D, Lassarre C, Gourmelen M 1984 Preferential measurement of insulin-like growth factor (IGF) I-related peptides in serum with the aid of IGF binding proteins (IGF BPs) produced by rat liver in culture. Estimation of serum IGF BP levels. J Clin Endocrinol Metab 59:453-462

28. Binoux M, Lassarte C, Gourmeien M 1986 Specific assay for insulin-like growth factor (IGF) Il using the IGF binding proteins extracted from human cerebrospinal fluid. J Clin Endocrinol Metab 63:1151-1155

29. Hardouin S, Gourmelen M, Noguiez P, Seurin D, Roghani M. Le Bouc Y Povoa G, Merimee TJ, Hossenlopp P, Binoux M 1989 Molecular forms of serum insulin-like growth factor (IGF) binding proteins in man: relationships with growth hormone and IGFs and physiological significance. J Clin Endocrinol Metab 69:1291-1301

30. Hossenlopp P, Seurin D, Segovia-Quinson B, Hardouin S, Binoux M 1986 Analysis of serum insulin-like growth factor binding proteins using Western blotting: use of the method for titration of the binding proteins and competitive binding studies. Anal Biochem 154:138-143

31. De Pagter-Holthuizen P, Jansen M, Van der Kammen RA, Van Schaik FMA Sussenbach JS 1988 Differential expression of the human insulin-like growth factor II gene. Characterization of the IGF-II mRNAS and mRNA encoding a putative IGF-II associated protein. Biochim Biophys Acta 950:282-295

32. Gluckman PD, Grumbach MM, Kaplan SL 1981 The neuroendocrine regulation and function of growth hormone and prolactin in the mammalian fetus. Endocr Rev 2:363-395

33. Hill DJ, Freemark M, Strain AJ, Handwerger S. Milner RDG 1988 Placental lactogen and growth hormone receptors in human fetal tissues: relationship to fetal plasma human placental lactogen concentrations and fetal growth. Clin Endocrinol Metab 66:1283-1290

34. Strain AJ, Hill DJ, Swenne I, Milner RDG 1987 Regulation of DNA synthesi in human fetal hepatocytes by placental lactogen, growth hormone and insulin-like growth factor I/somatomedin-C. J Cell Physiol 132:33-40

35. Frankenne F, Closset J, Gomez F, Scippo ML, Smal J, Hennen G 1988 The physiology of growth hormones (GHS) in pregnant women and partial characterization of the placental $\mathrm{GH}$ variant. J Clin Endocrinol Metab $66: 1171-1180$

36. Ashton IK, Zapf J, Einschenk I, MacKenzie IZ 1985 Insulin-like growth factors (IGF) 1 and 2 in human foetal plasma and relationship to gestational age and foetal size during midpregnancy. Acta Endocrinol (Copenh) 110:558563

37. Thiériot-Prévost G, Daffos F, Forestier F, Chartier M, Job JC 1987 Serum growth-promoting activity in normal and hypotrophic fetuses at midpregnancy. Pediatr Res 22:39-40

38. Foley TP, DePhilip R, Perricelli A, Miller A 1980 Low somatomedin activity in cord serum from infants with intrauterine growth retardation. J Pediatr 96:605-610

39. DeChiara TM, Efstratiadis A, Robertson EJ 1990 A growth-deficiency phenotype in heterozygous mice carrying an insulin-like growth factor II gene disrupted by targeting. Nature 345:78-80

40. Martin JL, Baxter RC 1986 Insulin-like growth factor-binding protein from human plasma. Purification and characterization. J Biol Chem 261:87548760

41. Wood WI, Cachianes G, Henzel WJ, Winslow GA, Spencer SA, Hellmiss R Martin JL, Baxter RC 1988 Cloning and expression of the growth hormonedependent insulin-like growth factor-binding protein. Mol Endocrino 2:1176-1185

42. Ballard J, Baxter R, Binoux M, Clemmons D, Drop S, Hall K, Hintz $R$ Rechler M, Rutanen E, Schwander J 1989 On the nomenclature of the IGF binding proteins. Acta Endocrinol (Copenh) 121:751-752

43. Drop SLS, Kortleve DJ, Guyda HJ 1984 Isolation of a somatomedin-binding protein from preterm amniotic fluid. Development of a radioimmunoassay. J Clin Endocrinol Metab 59:899-907

44. Povoa G, Enberg G, Jornvall H, Hall K 1984 Isolation and characterization of a somatomedin-binding protein from mid-term human amniotic fluid. Eur J Biochem 144:199-204

45. Povoa G, Isaksson M, Jörnvall H, Hall K 1985 The somatomedin binding protein isolated from a human hepatoma cell line is identical to the human amniotic fluid somatomedin-binding protein. Biochem Biophys Res Commun 128:1071-1078

46. Brinkman A, Groffen C, Kortleve DJ, Geurts van Kessel A, Drop SLS 1988 Isolation and characterization of a cDNA encoding the low molecular weigh insulin-like growth factor binding protein (IBP-1). EMBO J 7:2417-2423

47. Lee YL, Hintz RL James PM, Lee PDK, Shively JE, Powell DR 1988 Insulinlike growth factor (IGF) binding protein complementary deoxyribonucleic acid from human Hep G2 hepatoma cells: predicted protein sequence suggests an IGF binding domain different from those of the IGF-I and IGFII receptors. Mol Endocrinol 2:404-411

48. Hossenlopp P, Seurin D, Segovia-Quinson B, Binoux M 1986 Identification of an insulin-like growth factor binding protein in human cerebrospinal fluid with a selective affinity for IGF II. FEBS Lett 208:439-444

49. Binkert C, Landwehr J, Mary JL, Schwander J, Heinrich G 1989 Cloning, sequence analysis and expression of a $C D N A$ encoding a novel insulin-like growth factor binding protein (IGF BP-2). EMBO J 8:2497-2502

50. Gelato MC Kiess W, Lee L, Malozowski S, Rechler MM, Nissley P 1988 The insulin-like growth factor $\mathrm{II} /$ mannose-6-phosphate receptor is present in monkey serum. J Clin Endocrinol Metab 67:669-675

51. D'Ercole AJ, Willson DF, Underwood LE 1980 Changes in the circulating form of serum somatomedin-C during fetal life. J Clin Endocrinol Metab 51:674-676

52. Binoux M, Hossenlopp P 1988 IGF and IGF binding proteins. Comparison of human serum and lymph. J Clin Endocrinol Metab 67:509-514

53. Guler HP, Zapf J, Schmid C, Froesch ER 1989 Insulin-like growth factors I and II in healthy man. Estimations of half-lives and production rates. Acta Endocrinol (Copenh) 121:753-758 